\title{
Local Government Initiatives and Prospects for Mango Farming Community Capital Enhancement in Guimaras Province, Philippines
}

\section{Noe John Joseph Endencio Sacramento}

Political Science Program, College of Social Sciences, University of the Philippines Cebu Gorordo, Lahug, Cebu City 6000, Philippines

Corresponding author: nesacramento@up.edu.ph

\section{ABSTRACT}

Agricultural communities frequently encounter lack of support from various political actors. The local government units (LGUs) are responsible for initiating measures for improving community capitals towards fostering growth and development to mango farming communities. This descriptive qualitative study provides an understanding regarding the initiatives of the LGU in enhancing the community capitals in the Guimaras, Philippines mango farming community. The community capitals framework (CCF) served as a lens and guide. Semi-structured interview guides and participant observation are instrumental in data gathering from five key informants. Findings revealed that LGU provided various programs and initiatives to help enhancing the community capitals of the mango sector; thus, LGU as a political actor and development enabler has significant roles in fostering community development. Recommendations in this study are essential to the LGU further to enhance the community capitals of the mango farming sector. In gist, there is a crucial need to focus more on building social networks within the community, establish proper means for transporting the mango product, and strengthen community education on agriculture among the youth to be involved in the development of mango industry.
Article Info :

Article history :

Received: May 26, 2020

Revised: July 26, 2020

Accepted: September 5, 2020

Keywords:

community capital; local government; mango farming; initiative

\section{INTRODUCTION}

Agricultural communities are essential to develop societies since it produces and supplies food commodities (Webb et al., 2016). In Southeast Asian countries, for example, economies are heavily dependent on agricultural production for domestic consumption and international exports. Agriculture provides livelihood and source of income to communities to finance their essential daily needs for survival. However, our society often disregards the industry's rich and significant contribution to the economic life that often leads to the most miserable plight of our farmers, workers, and peasants. 
Generally, the existing oppressive social, economic, and political structures that continue to prevail in agricultural societies permit the marginalization of this sector in our community. To note, the Philippines has a very long history of agricultural development; hence, the country still struggles in uplifting the current status of the farming sector. Since the last decades of the 19th century, the Philippines have established various development initiatives and agenda for the agricultural sector. Interestingly, neighboring countries in the region have adopted some of these agendas and initiatives, which resulted in the enormous development of their agricultural industries.

Community development of agriculture-based societies is vital towards achieving progress and development in the industry in general. While it is necessary to look into the developments that institutions can instigate to the agricultural industries, it is also equally important to provide an enabling and empowered environment to communities for the people to respond to the needs of the society and overcome their marginalization and vulnerabilities. The field of community development enables people or residents to organize and mobilize their resources to accomplish defined goals (DeFilippis \& Saegert, 2013; Green \& Haines, 2015; Phillips \& Pittman, 2014; Robinson Jr \& Green, 2011). The purpose of community development is to produce certain assets, including the human, financial, and physical (environmental and natural resources) that will be useful for the community towards economic development (Phillips \& Pittman, 2014). Development, per se, not only denotes economic development but an improved life and standard of living of all the citizens. Community development of agricultural communities, in such a case, can be achieved if the local governments and organizations are able to work together with the communities to address their pressing needs and concerns. Essentially, the local government's role for development initiatives and interventions is vital towards achieving what is best for agricultural communities.

In focus, local governments have increasingly performed a vital role in addressing issues concerning sustainable development among various sectors in society. Green \& Goetting (2010) even noted that poor local communities often suffer limited social networks that foster lack of available jobs, employment opportunities even noted that poor local communities often suffer limited social networks that foster lack of available jobs, employment opportunities and social welfare and services that pose a great challenge and threat to local community life (Tigges, Browne, \& Green, 1998; Green \& Goetting, 2010). Governments are politically, socially, and economically accountable and responsible to their people. Increasingly, national governments have been devolving its responsibilities to the local governments to adequately address and respond to the needs of its people at the local level. Necessarily, local government units or LGUs are important political actors and enablers of agricultural industries in rural communities.

Community capital perhaps is an essential factor that drives agricultural community development and in fostering progress towards the industry. Agriculturalbased community development is very important to achieve progress and industrial development in general. Community development can be interpreted as a process of

112 | Journal of Local Government Issues (Logos), 3 (2), September 2020, pp. 111-129 ISSN : 2620-8091 print | 2620-3812 online 
change that requires organization, facilitation, and action. Inside, there is a vision, planning, direction, and coordinated action towards the desired goals (MatarritaCascante \& Brennan, 2012) such as promoting the (economic) welfare of society (Phillips \& Pittman, 2014c; Plunkett, Phillips, \& Ucar Kocaoglu, 2018) and solving social problems (Kumpulainen \& Soini, 2019). Generally, community development occurs in rural areas (Horlings, 2016) which is where social problems occur the most.

Community development is not only about providing the desired benefits but also related to the process of achieving the desired results (Mtika \& Kistler, 2017). The process contains practices and frameworks (Plunkett et al., 2018) that must be able to consolidate members of the community to work together (Jakimow, 2018; Lynch, Forde, \& Lathouras, 2020; Mtika \& Kistler, 2017) through participatory principles so that the results are more effective (Kenny, 2019). The key is consciously and actively involving the community, so it would shape the social capital.

Green \& Haines (2015) identified five essential forms of community capital. First, social capital that is mainly on the sustained strong relationship, networks, and connection among actors within and outside the community. Second, the human capital which includes labor supply, skills, capabilities, and experience. Third, the physical capital that focuses on the buildings, streets, and infrastructure; d) the financial capital including the community financial institutions, microloan funds, and community development banks. Fourth, the environmental capital involving the natural resources, weather, and recreational opportunities. In gist (Flora et al., 1992; Green \& Goetting 2010; Green \& Haines, 2015) provides the Community Capitals Framework or CCF presented in Table 1.

Table 1. The Community Capitals Framework

\begin{tabular}{ll}
\hline \multicolumn{1}{c}{ Capital } & \multicolumn{1}{c}{ Description } \\
\hline Financial & $\begin{array}{l}\text { Refers to the monetary and financial resources that can be directly } \\
\text { invested in other forms of capital (e.g., tax, philanthropic donations, } \\
\text { grants, contracts, regulatory exemption, loans, and forms of investment) }\end{array}$ \\
Physical/ Built & $\begin{array}{l}\text { Includes necessary infrastructure to support community activities such as } \\
\text { housing, transportation infrastructure, telecommunications infrastructure } \\
\text { and hardware, utilities (e.g., water treatment, sewer, sidewalks), } \\
\text { Social } \\
\text { recreation facilities, and community buildings } \\
\text { Refers to the connections/network between individuals, and the level of } \\
\text { trust, norms of reciprocity, and cooperation they maintain. It also reflects } \\
\text { the common vision and goals, acceptance of alternative views, and diverse } \\
\text { representation within discussions made about the community } \\
\text { Focuses on the knowledge, skills, and competencies of individuals who } \\
\text { can be used to foster the community development, particularly leadership. } \\
\text { Also includes health and well-being, level of creativity, demographics of } \\
\text { community members, and intrinsic qualities (e.g., self-esteem, self- } \\
\text { efficacy, and respect) } \\
\text { Includes the stock of natural resources, beauty, and geography that } \\
\text { characterize the community as a place (e.g., air quality, land, landscapes, } \\
\text { water features, water quality, biodiversity, scenery, and natural resource }\end{array}$ \\
Environmental/ \\
Natural
\end{tabular}

113 | Journal of Local Government Issues (Logos), 3 (2), September 2020, pp. 111-129 ISSN : 2620-8091 print | 2620-3812 online 
protection)

\section{Source: Adapted from (Flora et al., 1992; Green \& Goetting, 2010; Green \& Haines, 2015)}

Essentially, LGUs need to consider these forms of capital in developing local agricultural communities. Wichtner-Zoia (2013) mentioned that "community capitals play an integral role in the economic and community development of an area." These are resources and characteristics identified in a successful and sustainable society. Potentially, focusing and assessing the community capitals of a particular area will, therefore, guide the LGUs in providing cohesive and sustainable development interventions and initiatives for the agricultural sector.

Various studies have explored the agricultural communities through CCF and the role of governments toward community development. Duffy, Kline, Swanson, Best, \& McKinnon (2017) provide the potential linkages of agroecology and sustainable tourism development goals for community development using the CFF. Lima \& d'Hauteserre (2011) provided in their study that the developments in ecotourism significantly contribute to enhance the human, social, and natural capitals of a community. On the other hand, Anglin (2010) cites that "local public sector, city governments, country governments, and other area governments are critical forces in the widespread use and support of community economic development." The public sector, and specifically the local government, has an impact on community planning and resource allocation towards community development (Aarsaether \& Ringholm, 2011). Undeniably, local governments have a vital role in providing services and expertise towards developing the local community. Especially for social capital, its strength lies in its ability to enhance community members to cooperate sincerely and sustainably (Beukes, 2019; Rahman \& Yamao, 2007) and is proven to be able to improve the farmer's economy (Sutherland \& Burton, 2011).

While agriculture in the Philippines has been the backbone of the country's economy since then, it is equally crucial that societies will focus its attention to the mango industry which has increasingly become popular and also considered as a vital fruit export commodity that drives the economy, third to banana, and coconut. Community capitals in mango farming industries need an assessment and an enabler's intervention for community development. Also, limited studies have been focusing on investigating the community capital of these societies, and it is equally significant that this essay will be investigating on how the local government partakes in enhancing it. Anglin (2010) even articulated that it is increasingly important to have a documentation and administrative analysis on the innovations instigated by the local government in linking its people towards developing the community. This study will give an understanding regarding the importance of community capitals in the mango farming industry in Guimaras Province, Central Philippines. This essay will first present the existing initiatives that the LGU has initiated as an intervention towards developing the mango farming communities using the community capitals framework CCF (Flora et al., 1992; Green \& Goetting, 2010; Green \& Haines, 2015). Then, it will provide a recommendation for the local government on necessary factors in the CCF that need the most attention towards mango farming community development.

114 | Journal of Local Government Issues (Logos), 3 (2), September 2020, pp. 111-129 ISSN : 2620-8091 print | 2620-3812 online 


\section{METHOD}

This study employed qualitative methods in research. This research will present a narrative on the roles and initiatives that the LGU of the province of Guimaras in the Philippines undertook to develop the mango farming community. The qualitative method is the most feasible to use in this study since it will provide a thorough understanding of the local government's action towards the Guimaras mango industry. Hill (2012) highlighted that the qualitative case study research is essential to understand the social and political world. The qualitative method provides a room for a different perspective in understanding a highly constructed socio-political world (Hill, 2012).

Further, the qualitative method is the most feasible means to elucidate the facts and discuss the findings of the study. It also provides an insight to the reader on the social realities and the current status of mango farming in Guimaras. As to the analysis, it will aid in providing an in-depth discussion on the implications of the findings to the existing community development measures of the LGU, also will be useful guides towards providing a comprehensive suggestion for initiative, as well interventions needed for further developing the community and the mango sector.

The province of Guimaras, Philippines, is the study site of this study since its mango agri-tourism industry is the most popular in the country (see Figure 1). Mango is an essential fruit export commodity of the Philippines third to coconut and banana, and since 1995, the Guimaras province has been participating in the industry. Moreover, mango production attracts tourism while it showcases the produce of the farmers and other food products by the local mango food manufacturing factories.

In answering the research question and objectives, the study utilized a semistructured open-ended interview guide to gathering the necessary data from 5 key informants from the LGU and the local cooperative which includes the Provincial Office for Agricultural Services POAS, the Provincial Planning and Development Office PPDO, the Sangguniang Panlalawigan SP or Provincial Legislative Board, the Vice Governor, and the president of the Guimaras Mango Growers and Producers Development Cooperative GMGPDC. Hill (2012) mentioned that it is important to utilize open-ended questionnaires for participants to talk openly and free state their knowledge or opinion about a certain topic in focus. Additionally, small samples are ideal for providing a deeper understanding of the problem and key informants to speak articulately about their experience (Hill, 2012). Participant observation is also necessary to this study since the researcher was also directly immersed and connected to GMGPDC as a consultant and community development practitioner assisting the organization for development initiatives and agenda for the mango industry. Recordings, note-taking, and taking of pictures are techniques used in securing the data. Transcription of recording is instrumental in processing the data. The study utilized thematic analysis in treating the data. Coding is an essential technique in the categorization of the data based on the community capitals framework. The presentation of data is in a narrative style utilizing the CCF as a guide in organizing the flow of thoughts in the results and discussions.

115 | Journal of Local Government Issues (Logos), 3 (2), September 2020, pp. 111-129 ISSN : 2620-8091 print | 2620-3812 online 


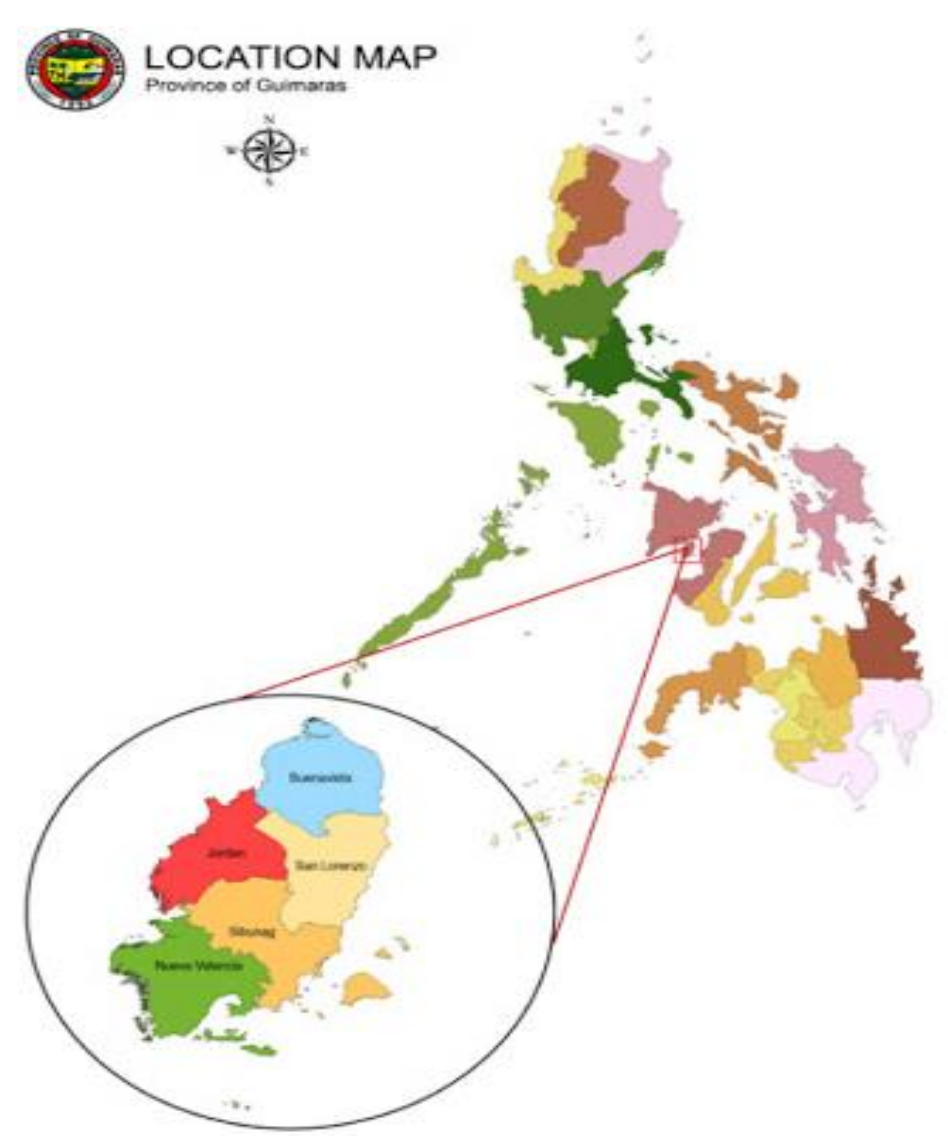

Figure 1. Map of the Province of Guimaras in the Philippines (Study Site) Source: (Sea Knowledge Bank, 2020)

The study has undergone a research ethics review, and the team of the researcher observed ethical procedures in gathering the data, processing, and analysis. Likewise, the triangulation of data is instrumental in verifying that the claims in this study are valid. The researcher presented the study before the LGU and the GMGPDC to collect their insights and validate the information presented. The study is, however, delimited in gathering the data from the LGU and the GMGPDC, and has focused solely on the initiatives that the local government instigated to develop the mango industry.

\section{RESULTS AND DISCUSSION \\ Mango Farming Community and Local Governance}

Local governance is essential towards development, and most communities in rural areas are highly dependent on local government to provide the important needs of the community and to promote progress. Nonetheless, NGOs and Peoples Organizations also supports LGUs to meet the needs of the community and to alleviate the people from issues and concerns they face. All these actors are important in community development. However, in the context of community governance, it is the community plays a central role in making local governments accountable and effectively implementing development programs, such as the distribution of agricultural inputs (Otsuka \& Kalirajan, 2010). Herewith, it is the role of LGUs to ensure that in local 
communities, especially the industries of the farming sector, are sustainably monitored and provided with essential help to safeguard development.

\section{LGU's Initiatives in Enhancing the Mango Farming Community Capitals}

Flora et al., (1992) asserts that in maintaining and fostering development to communities, the community capitals are vital to consider in guaranteeing that members of communities are empowered. The following discussion will provide how far had the local governments intervened and initiated local developmental agendas and policies to respond to the needs of the mango farming community in the province of Guimaras, Philippines (see Table 2). Also, the next sections will substantially discuss the financial, physical, social, human, and environmental capitals as stipulated in the CCF.

Table 2. LGU's Initiatives Towards Community Capitals Enhancement

\begin{tabular}{|c|c|}
\hline Capital & LGU's Initiatives \\
\hline Financial & $\begin{array}{l}\text { - Assisted in establishing the GMGPDC, a mango grower } \\
\text { cooperative, in serving as an organization to promote technical } \\
\text { assistance, marketing and trading, and credit facility to farmers } \\
\text { - Provided one million pesos start-up capital to GMGPDC } \\
\text { - Provided input materials to ease the production of small-scale } \\
\text { mango producers }\end{array}$ \\
\hline $\begin{array}{l}\text { Physical or } \\
\text { Built }\end{array}$ & $\begin{array}{l}\text { - Built Farm to Market Roads in collaboration with the national } \\
\text { government and the UNDP } \\
\text { - Constructed a Post-Harvest and Treatment Facilities } \\
\text { - Established a provincial center for mango trading and } \\
\text { marketing }\end{array}$ \\
\hline Social & $\begin{array}{l}\text { - Ensured connections with domestic and foreign investors } \\
\text { - Connected with local and international developmental } \\
\text { organizations towards development projects and programs } \\
\text { - Established networks with other LGUs to promote agriculture } \\
\text { and tourism }\end{array}$ \\
\hline Human & $\begin{array}{l}\text { - Provided technical skills development training to farmers and } \\
\text { producers } \\
\text { - Provided training and workshops for strategic planning, } \\
\text { business planning, and marketing }\end{array}$ \\
\hline $\begin{array}{l}\text { Environmental } \\
\text { or Natural }\end{array}$ & $\begin{array}{l}\text { - Passed resolutions and ordinances regulating the mango } \\
\text { production and harvesting } \\
\text { - Implemented the provincial environmental code } \\
\text { - Established plant quarantine facilities to prevent the entry of } \\
\text { other variety of mango fruits and seedlings }\end{array}$ \\
\hline
\end{tabular}

Source: Summarized from Interviews of Key Informants

117 | Journal of Local Government Issues (Logos), 3 (2), September 2020, pp. 111-129 ISSN : 2620-8091 print | 2620-3812 online 


\section{Financial Capital}

In industries, financial capital is a vital factor that needs to be maintained to ensure progress and development. Specifically, local agricultural communities always complain about their financial incapacities to meet the demands and needs of production and enhance their capacity towards fulfilling the requirements of the local economy. From the provincial budget allocation and spending report in 2019, the local government has collected total revenue of 940 million pesos that will be divided and allocated in various spending. For economic servicing, the LGU has allocated 271 million pesos or $28.30 \%$ from the total revenues (see Table 3). The province includes $20 \%$ allotment for agricultural services that will include inputs for the mango economy.

Table 3. Local Revenues and Allocation for the Mango Economy

\begin{tabular}{ll}
\hline \multicolumn{1}{c}{ Revenues } & Amount \\
\hline Local Sources & Php 138,613,790.84 \\
Tax Revenues & Php 38,722,071.41 \\
Non-Tax Revenues & Php 99,891,719.43 \\
External Sources & Php 801,582,470.65 \\
\multicolumn{1}{c}{ Total } & Php 940,196,261.49
\end{tabular}

Allocation for Agriculture

Economic Services

Percentage from the Total Revenues

Agricultural Industry Allocation (Including Mango Industry)
Php 271,730,815.69

$28.30 \%$

$20 \%$ from the Economic

Services

\section{Source: (Guimaras, 2019)}

The LGU has included the mango economy to their yearly spending of financial resources since the annual mango festival attracts tourism. The government has concluded that it is worth investing, and they have started to shed assistance to mango farmers in terms of procuring agricultural inputs for the abundant production of mangoes. Also, the LGU has been keen on ensuring that mango trees are well propagated. They have acquired mango seedlings through the budget allocation and distributed it to mango orchards and farms. Likewise, the budget allocation enables the offering of various programs on the asexual propagation of mango trees to increase the production of mango fruit.

The LGU has assisted in putting up a cooperative for mango growers and farmers to assist in the financial needs of the sector. The cooperative, being financially subsistence, aims to provide a credit facility to the mango producers in financing the needs for production at a reasonable interest rate. In principle, cooperatives govern in the spirit cooperation; thus, the interests from credits are not for profit, but an additional financial capital to help other members who are in need. Additionally, the

118 | Journal of Local Government Issues (Logos), 3 (2), September 2020, pp. 111-129 ISSN : 2620-8091 print | 2620-3812 online 
LGU provided the GMGPDC a start-up capital amounting to one million pesos to finance its immediate needs from its revival in 2017. Despite its founding as LGU initiated, the GMGPDC maintained its autonomy. In 2019, the provincial government had even more extended 1.8 million pesos aid to the cooperative to reinforce its production (Guimaras, 2019). One of the informants mentioned:

"...yearly ga appropriate ang provincial government sang support to the mango gahatag kita inducer for the mango growers sa coop para sa ila yearly nga production schedule para makainduce sila supoort sa manggahan. Tapos may ginhatag, daw loan sa coop nga every cutting season ang kwarta nga 1 million ginagamit nila for their inputs, bagging, labor. [The provincial government appropriates a yearly budget to support the procurement of inducers for the production of mangoes. The government helps the cooperative to reinforce the supply needed for the mango festival. Then, the government also provides the 1 million grants for the cooperative to use a loan for farmers for the production inputs.]" - Informant A

At the same time, the Department of Agriculture and the Provincial Office for Agricultural Services (POAS), in collaboration with the GMGPDC, have worked together to receive an 18 million pesos worth of capital investment from the World Bank, which will be used for an infrastructural project in the mango industry. As a condition for this investment, the provincial government also provided its share to materialize the project. From the interview, an informant said:

“...actually, nag counterpart ang province mga about 2.8 or about 3 million sa project sang World Bank sa mango production, consolidation, and marketing for the growers. [Actually, the province provided about 2.8 or 3 million counterparts to the project of the World Bank on mango production, consolidation, and marketing for the mango growers]" Informant $A$

In other capacities, the LGU also extended assistance to mango farmers through the POAS through some of the inputs for production, such as mango seedlings, inducing chemicals, and fertilizers, to ease the financial burden of farmers. The farmers can also access these on a crop center stationed in the province named Guimaras National Crop Research Development, Production, and Support Center (GNCRDPSC).

\section{Physical or Built Capital}

Physical or built capital is also significant to ease the production of mangoes in the local farming community. Infrastructures and buildings will help from the process of production, transport of necessary needs in maintaining mango orchards, transport of products from farms to market, conducive and reliable storage and treatment facilities, and centers for trade and marketing. Green \& Goetting (2010) added that built capital is essential towards shaping the introduction of financial capital to local communities.

The local government, in this case, has provided enough for the local farming

119 | Journal of Local Government Issues (Logos), 3 (2), September 2020, pp. 111-129 ISSN : 2620-8091 print | 2620-3812 online 
community. The LGU has constructed roads that connect farms to national highways and the market (see Figure 2). The fund came from the existing national budget, as proposed to the national government. The LGU, together with the GMGPDC, has secured the funding from the UNDP and World Bank to finance the construction of other roads not covered by the national government. In turn, the LGU has also shared an amount to the total cost of construction with the UNDP and World Bank.

"...So consctruction ongoing karon... diri na sa gaagi sa Bugnay to Sibunag. So ang next naton kay syempre requirement man sang World Bank dapat ang imo infrastructure magsupport sa enterprise. So amo na subong ang ginprograman naton ang enterprise for the mango production which is based on marketing amo na almost 19 million sa ila livelihood na. So, meaning after that kung may window pa, we can propose for another farm to market roads para maglink bala, pero kung din to aton mango orchard kung problemado ila dalan, idevelop to para ang product makagwa sa market. [So, the construction is ongoing... it passes through Bugnay and Sibunag. The next requirement of the World Bank is for the infrastructure to support the enterprise. So, we have crafted programs on the enterprise worth 19 million for the livelihood from the mango production, which we will focus mainly on marketing. After this, we propose another project to link other orchards which has problematic roads to connect the products to the market.]" - Informant E

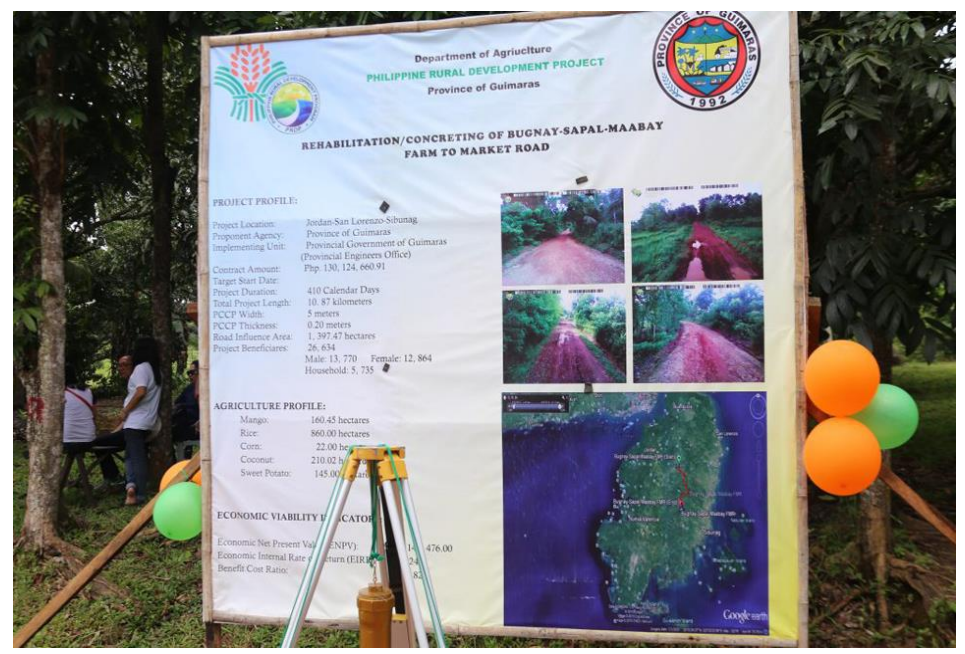

Figure 2. Farm to Market Road Project (Bugnay-Sapal-Maabay Road) Source: (Department of Agriculture Philippine, 2017)

Furthermore, the LGU, together with the Department of Agriculture, provided a post-harvest and treatment facility for the mango produce to maximize and increase the shelf life of the products (see Figure 3). The facility will ensure that the mangoes are still salable and free from deterioration before it reaches the market to ensure a profit and prevent losses for the producers. An informant mentioned:

120 | Journal of Local Government Issues (Logos), 3 (2), September 2020, pp. 111-129 ISSN : 2620-8091 print | 2620-3812 online 
"..Oo, ti subong may duwa kami ka unit. Ang isa iya sang DA hatag, ang isa iya sang DTI. Hot water treatment. Tapos may packing house man kami nga iya man sang DTI hatag. Amo na mga worth 6-million-man san-una. Ang gina-process namon subong kay nag-submit kami business plan sa PRDP. [Yes, we have two units now. The one is a donation from the DA, and the other is from the DTI. We also have a packing house that was given by the DTI. That's why it is worth 6 million before. We are processing the business plan to submit to the PRDP.]" - Informant C

As seen in Table 4, the major crop is mango; thus, the facility is needed to ensure the marketability and quality of these products. The provincial government even looks forward to increased production of 22 metric tons by 2022. Similarly, the LGU established a center for the GMGPDC for the organization to house its members during meetings and for them to be physically visible. The center will also help for easy access for other members on programs and projects initiated by the GMGPDC.

Table 4. Average and Target Production of Agricultural Commodities in the Province of Guimaras

\begin{tabular}{ccc}
\hline & \multicolumn{2}{c}{ Production MT } \\
\cline { 2 - 3 } Commodity & $\begin{array}{c}\text { Baseline } \\
\text { (average, 2009- }\end{array}$ & Target (2022) \\
& 2015) & $13.7 \mathrm{MT}$ \\
Mango & 9,306 & $1,102 \mathrm{MT}$ \\
Cashew & 568 & $1,800 \mathrm{MT}$ \\
Seaweeds & $1,212.5783$ & 55 \\
Cacao & 1.88 & 52 \\
Coffee & 18.8 & \\
\hline
\end{tabular}

Source: (Guimaras, 2020)

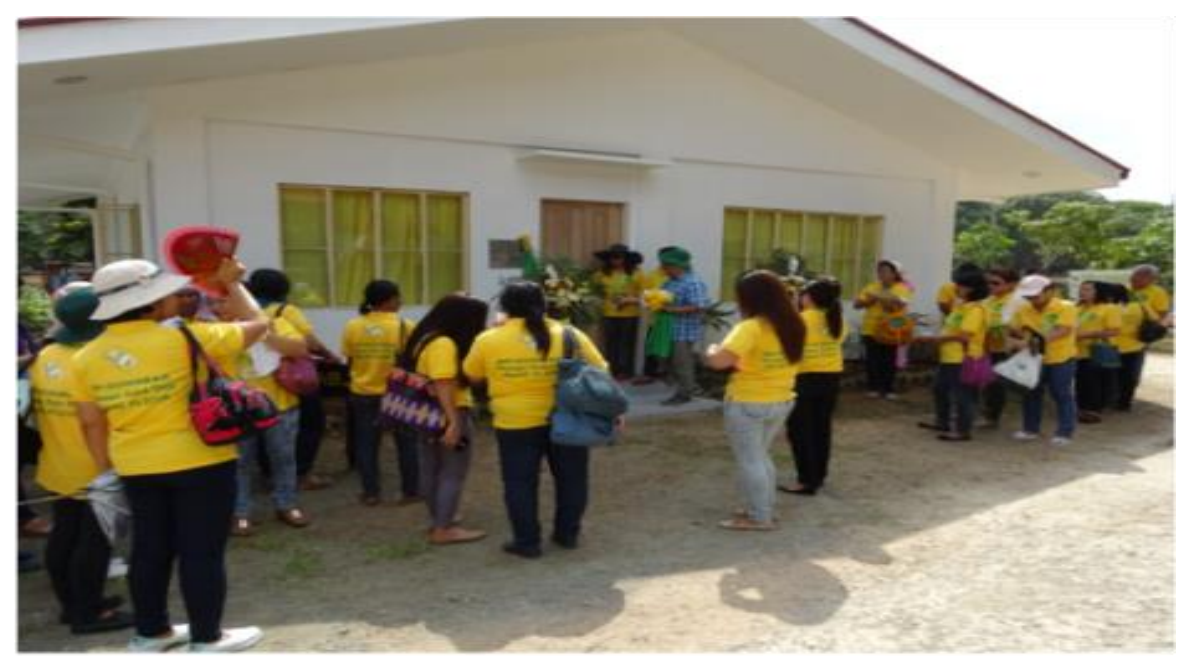

Figure 3. Newly Established Post Harvest Facility for Mango Industry Source: http://bpi.da.gov.ph/bpi/images/Picture/guim2.png 


\section{Social Capital}

The LGU also had a fair share in helping the community in strengthening its social capital. Mainly, its initiatives center on how it can build connections with local, national, and international organizations outside the local mango farming community towards instigating development in the industry. The LGU primarily has invested much of its efforts in connecting with other local governments in promoting the mango agricultural produce and strengthening ties for agri-tourism development. The manggahan or mango festival as an annual province-wide celebration has established a network among local government units and provided developments to community capital. Local tourists and from other countries flock in the province every April and May to witness the festival and enjoy the scenic view that that most of the tourist spots have to offer. In fact, the provincial government focuses a lot of effort in this festival to showcase the mangoes, and to increase production (see Table 5). As shown in Table 6, the tourist's consumption of mangoes during the "mango eat all you can" event increased in 2018 from its precedent years, which shows that more and more tourist have been coming to Guimaras to join and celebrate for the festival that adds ups to the tourism revenues of the province.

Table 5. Mango Production for Manggahan Festival

\begin{tabular}{cc}
\hline Year & Volume in Metric Tons \\
\hline 2013 & $10,138 \mathrm{MT}$ \\
2014 & $10,026 \mathrm{MT}$ \\
2015 & $11,840 \mathrm{MT}$ \\
2016 & $11,085 \mathrm{MT}$ \\
2017 & $11,239 \mathrm{MT}$ \\
\hline
\end{tabular}

Source: (Philippine Statistics Authority, 2018)

Table 6. Guimaras Manggahan Festival “Mango Eat All You Can” Data (Comparative, 2016-2018)

\begin{tabular}{ccc}
\hline Year & $\begin{array}{c}\text { Number of } \\
\text { Participants }\end{array}$ & $\begin{array}{c}\text { Consumption } \\
\text { (In Kgs.) }\end{array}$ \\
\hline 2016 & data not available & $6,800.00$ \\
2017 & 5,456 & $9,828.29$ \\
2018 & 9,962 & $17,100.80$ \\
\hline
\end{tabular}

Source: (Philippine Statistics Authority, 2018)

Essentially, the LGU has also propelled the interest of national and international investors to finance the mango production in the province. Local financiers and farmers connect to these investors and establish their terms. Not only that, but these investors also finance the local tourist spots and sites since it is also vital towards rural economic 
development. The connections that the LGU helped to establish is indeed beneficial to the community.

Green \& Goetting (2010) emphasized that improving social capital refers to an advantage to the finances and economic capital of a community (Green \& Goetting, 2010; Putnam, 2007; Tigges et al., 1998). An increase in the number and a strong establishment of relationships between individuals and associations inside and outside the community will greatly help the mango farming community (Green \& Goetting, 2010). This will eventually help in securing jobs and the economic well-being of the people in the community. Putnam (2007) also added that in times of economic stress, social networks could help the people, as well as advancing democratic practices.

\section{Human Capital}

Human capital is important to establish development in the local farming community since the individuals living within the community are themselves the main proponents of this agenda. Green \& Goetting (2010) cite that human capital primarily refers to the education levels, training, skills, and aptitudes of the community residents. Some informants mentioned that:

"...gaconduct lang kami training for additional nga mga baggers kay kulang pa gid kag daw ang skills sa pagpamotos... makabakal kami support sa ila nga gear equipment for bagging kay... ti ang ila da gani hambal na skillful man sila pero mas ano gid kung appropriate ang gear e kay safety gid sila. [We are conducting training for additional baggers because they lack the skills on how to bag or wrap... we will buy gears and equipment in bagging to support them... they were saying that they are already skillful but it is still important that they have the appropriate gears and they are safe.]" - Informant D

"...Actually ang sa entrepreneural... part of education process naton pero ang enterprise aspect gid ya bala in the business diri kami nagbulig sa coop gid ya kay meaning ginatan-aw namon kung sila ang magrun sang business bala... ang iban nga members later mabenepisyohan pa kung may viable nga enterprise nga naga exist sa province. [Actualy, on the entrepreneurial, it is part of the education process of the enterprise since it is business-oriented, and we can help the coop on running the business... other members can benefit from this if there is a viable enterprise that exist in the province.]" - Informant $C$

"...usually ang gapatawag kundi ang province amo na ang communications kay ang mga participants stakeholders man sang mango. Ang sa amon lang siguro, ang sa coop mag-free membership training $\mathrm{ka}$ lang. [...usually it is the province who will call and communicate with us since the participants are stakeholders of the mango industry. On our side, we have free coop membership training]"Informant $E$ 
The LGU has also provided profound initiatives to build the human capital of the mango farming community. Through the POAS as the main implementor and with the assistance from GMGPDC, the mango growers, and farmers receive knowledge and skills development training on mango propagation and production. The Provincial Economic Development Office also helps in the capacitation of the GMGPDC through various training on marketing, strategic planning, and organizational management. Similarly, the LGU, in collaboration with Technical Education and Skills Development Authority TESDA, also provides short certificate courses on agricultural farming.

\section{Environmental or Natural Capital}

Environmental or natural capital is as equally important along with other identifies community capitals. Sustainably maintaining natural capital means keeping the life of the community, the growth of the economy, and the survival of every individual. Green \& Goetting (2010) point out that environmental capital includes the land, soil, water, and other natural resources that are advantageous for community development.

In keeping this, the local government has initiated measures in preserving and keeping the environment healthy that can sustainably provide for the mango production. The LGU passed a local environmental code that aims to protect the natural resources from overuse, misuse, and exploitation. The code also cites the use of natural resources in Guimaras province is solely for the benefit of its people, while it highly regulates outsider's interference (ILO, 2010).

In line with the mango production, the local government also passed a resolution and ordinance regulating the use of hazardous chemicals as inducers, pesticides, and insecticides. In turn, the LGU, together with line offices and agencies, promotes the use of organic inputs chemicals and materials for mango production, which is important for the protection of the environment, the workers, and consumers. At the same time, organic-based chemicals are more economically efficient since materials are locally available for manual production. An informant mentioned:

"...Actually, subong ang priorities naton is towards organic meaning while we handle chemicals, kay ang World Bank strikto sa chemicals, so ang amon ginpurchase are duly registered nga chemicals for mangoes. [Actually, our priorities now are on the use of organic while handling chemicals at the same time, since the World Bank is very strict with chemical, what we purchase is only the duly registered ones for mango production use]" - Informant A

"...subong damo naman sang mga chemicals nga organic-based.... kami gani san-una grabe gid kami mag-gamit synthetic ya. Massive gid ya. Subong gina-amat amat naman namon para maka-save kag ang effect ya dugay, ga amat-amat kami save sa mga produkto nga organic. [...there are a lot of chemicals that are organic-based now... before we are heavy users of synthetic chemicals. Massive. We are minimally changing it now so that we can save the environment and its lasting

124 | Journal of Local Government Issues (Logos), 3 (2), September 2020, pp. 111-129 ISSN : 2620-8091 print | 2620-3812 online 
effect, while we also save our mango trees and organic products.]" -

Informant $E$

Similarly, the LGU implemented quarantine measures in prohibiting the import of mango fruits and seedlings to the province to protect the breed and quality and to free the mango plants from diseases. This aligns with the existing Presidential Proclamation No. 314 of 1993 (see Figure 4). The LGU has established quarantine centers at the entry ports of the province to intercept the prohibited entry (see Figure 5). Nevertheless, the measures that the LGU provided and implemented gears towards the enhancement of the mango farming community.

\section{MALACAÑANG}

MANILA

DECLARING THE ISLAND OF GUIMARAS AS A "SPECIAL QUARANTINE ZONE," AN AREA FREE FROM MANGO PULP WEEVIL AND MANGO SEED WEEVIL AND PROVIDING MEASURES TO MAINTAIN SUCH
STATUS.

WHEREAS, Philippine mango fruits have very high potentials for export, the production thereof should require full support and protection by the government.

WHEREAS, the Manila Super Mango is one among the most delicious mango in the world.

WHEREAS, the Island of Guimaras in the Visayas is the leading producer of the above-mentioned mangoes and has become a major industry in that island.

WHEREAS, it has been finally established that the island of Guimaras is free from injurious mango pests, such as the mango pulp weevil and the mango seed weevil.

WHEREAS, it is very necessary at appropriate mechanisms and measures be provided by the government to prevent witting or unwitting introduction into Guimaras Island of the above-mentioned pests of mangoes which might be existing in other parts of the country.

WHEREAS, maintaining the Island of Guimaras as free from infestation of the above-said mango pulp and seed weevils will enhance our mango exports to U.S. markets and other foreign markets.

WHEREAS, progressive exports of our mangoes to foreign markets would result to additional foreign exchange earning of our country.

NOW, THEREFORE, I, FIDEL V. RAMOS, President of the Republic of the Philippines, by virtue of the powers vested in me by law, hereby declare the Island of Guimaras a "Special Quarantine Zone," an area free from the infestation of mango pulp weevil and mango seed weevil. To effectively maintain such free-area status, the Plant Quarantine Service of the Bureau of Plant Industry with the approval of the Secretary of Agriculture provide the necessary organizational structure/mechanism and measures to carry out the same. The Secretary of the Budget is hereby instructed to provide such funds as are needed to support this activity.

DONE in the City of Manila, this $23^{2}$ day of Decemper in the year of Our Lord, nineteen hundred and ninety-three.
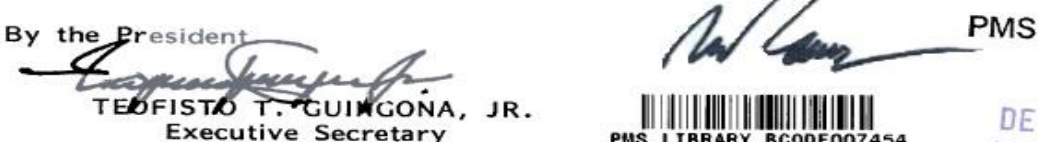
Executive Secretary

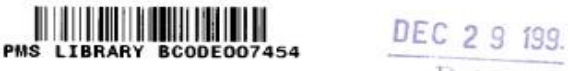

Figure 4. Presidential Proclamation No. 314

Source: (Official Gazette Republika Ng Philipines, 2020) 

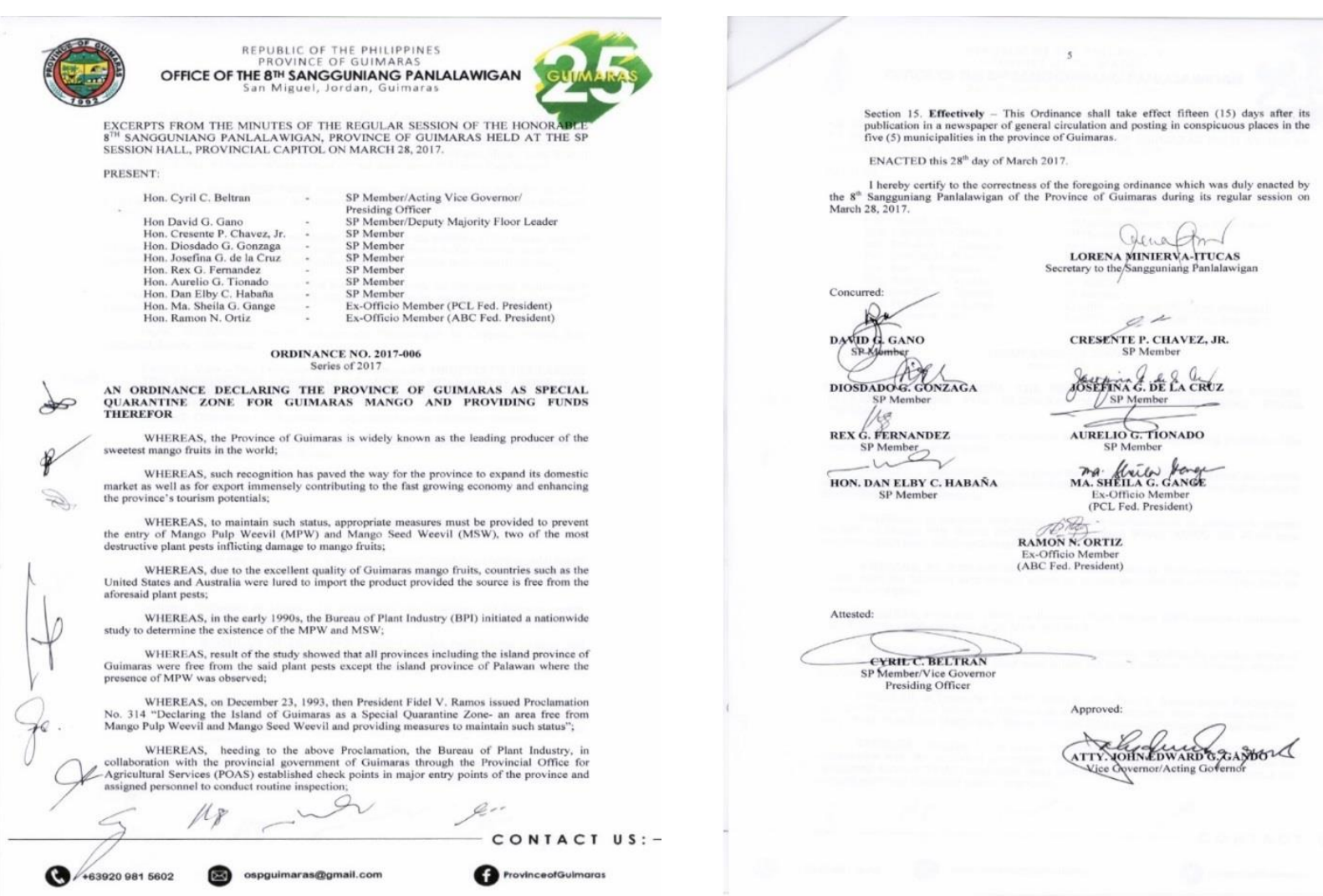

Figure 5. Provincial Ordinance on Mango Quarantine Zone Source: (Guimaras, 2020)

\section{CONCLUSION}

This study presents the initiatives of the local government of the province of Guimaras in the Philippines towards the enhancement of mango farming community capitals. The CFF framework was instrumental in understanding the case based on the data provided by the key informants, while community capitals are important to the development. The farming community needs the assistance of various actors to enable them to respond to its needs and address their concerns. Indeed, the LGU of the province of Guimaras has performed a significant role in maintaining community capital. Undeniably, the LGU as a political actor has an essential role in community development, though not as the main performer, but as an enabler that will provide the means for the community to be empowered.

With this regard, the LGU also needs to consider some suggestion for the sake of empowering its community by providing the necessary interventions towards community capitals enhancement. The LGU may consider a cash-for-work grant to small scale local mango farmers and producers who cannot afford the means for production, at the top of the existing facilities with the cooperative. Physical capital can be 
operational if the transport services are available so the farmers can utilize at the most economical terms since the majority of the facilities and mango orchards are in the remote areas. Despite the efforts of building networks with outside investors, the LGU should also strengthen community-based associations and networks for them to be fully empowered. The LGU can also consider promoting the agriculture and mango industry towards the younger generation to motivate their interest to be involved in mango farming as it is important towards developing human capital. Nonetheless, the Guimaras mango farming community has potentially provided and beneficial for the local agriculture and tourism economy.

\section{REFERENCES}

Aarsaether, N., \& Ringholm, T. (2011). The Rural Municipality as Developer Entrepreneurial and Planning Modes in Community Development. Lex LocalisJournal of Local Self-Government, 9(4). https://doi.org/10.4335/9.4.373-387

Anglin, R. V. (2010). Promoting Sustainable Local and Community Economic Development. London: CRC Press.

Beukes, J. W. (2019). Leveraging Social Capital of the Church for Development: A Case Study of A Farming Community in Wellington. HTS Theological Studies, 75(4), 110. https://doi.org/10.7832/44-2-138

DeFilippis, J., \& Saegert, S. (2013). The Community Development Reader. New York: Routledge.

Department of Agriculture Philippines. (2017). Rehabilitation/Concerting of BugnaySapal-Maabay Farm To Market Road. https://www.da.gov.ph/wpcontent/uploads/2017/08/IMG_2471.jpg

Duffy, L. N., Kline, C., Swanson, J. R., Best, M., \& McKinnon, H. (2017). Community Development Through Agroecotourism in Cuba: An Application of the Community Capitals Framework. Journal of Ecotourism, 16(3), 203-221. https://doi.org/10.1080/14724049.2016.1218498

Flora, C. B., Flora, J., Spears, J., Swanson, L., Lapping, M., \& Weinberg, M. (1992). Rural Communities: Legacy and Change. New York: Westview Press.

Green, G. P., \& Goetting, A. (2010). Mobilizing Communities. Philadelphia: Temple University Press.

Green, G. P., \& Haines, A. (2015). Asset Building \& Community Development: London: Sage Publications.

Guimaras, P. o. (2019). Guimaras Mango Growers get PHP 1.8-Million Aid. https://guimaras.gov.ph/news-and-updates/guimaras-mango-growers-get-php-18-million-aid/

Guimaras, P. o. (2019). Statement of Receipts and Expenditures. https://guimaras.gov.ph/wp-content/uploads/2020/06/SRE-Trust-Fund.pdf

Guimaras, P. o. (2020). Agriculture and Fisheries. https://guimaras.gov.ph/agriculturefisheries/

Guimaras, P. o. (2020). An Ordinance Declaring the Province of Guimaras as Special Quarantine Zone for Guimaras Mango and Providing Funds Therefor.

127 | Journal of Local Government Issues (Logos), 3 (2), September 2020, pp. 111-129 ISSN : 2620-8091 print | 2620-3812 online 
.https://guimaras.gov.ph/wp-content/uploads/2018/12/2017-006.pdf

Hill, C. E. (2012). Consensual Qualitative Research: A Practical Resource for Investigating Social Science Phenomena. Washington: American Psychological Association.

International Labour Organization. (2010). Local Economic Development and Youth Employment in the Philippines: The Case of Guimaras Province. https://www.ilo.org/wcmsp5/groups/public/---asia/---ro-bangkok/---ilomanila/documents/publication/wcms_149585.pdfs

Horlings, L. G. (2016). Connecting People to Place: Sustainable Place-Shaping Practices as Transformative Power. Current Opinion in Environmental Sustainability, 20, 32-40. https://doi.org/10.1016/j.cosust.2016.05.003

Jakimow, T. (2018). Volunteering and Citizenship in Indonesia: Practices of Care as a Model for State-Citizen Relations. Citizenship Studies, 22(2), 145-159. https://doi.org/10.1080/13621025.2018.1445491

Kenny, S. (2019). Framing Community Development. Community Development Journal, 54(1), 152-157. https://doi.org/10.1093/cdj/bsy034

Kumpulainen, K., \& Soini, K. (2019). How do Community Development Activities Affect The Construction of Rural Places? A Case Study from Finland. Sociologia Ruralis, 59(2), 294-313. https://doi.org/10.1111/soru.12234

Lima, I. B., \& d'Hauteserre, A.-M. (2011). Community Capitals and Ecotourism for Enhancing Amazonian Forest Livelihoods. Anatolia, 22(2), 184-203. https://doi.org/10.1080/13032917.2011.597933

Lynch, D., Forde, C., \& Lathouras, A. (2020). Changing Contexts of Practice: Challenges for Social Work and Community Development. Australian Social Work, 73(2), 245-253. https://doi.org/10.1080/0312407X.2019.1694047

Matarrita-Cascante, D., \& Brennan, M. A. (2012). Conceptualizing Community Development in the Twenty-First Century. Community Development, 43(3), 293305. https://doi.org/10.1080/15575330.2011.593267

Mtika, M. M., \& Kistler, M. (2017). Contiguous Community Development. Journal of Rural Studies, 51, 83-92. https://doi.org/10.1016/j.jrurstud.2017.01.018

Official Gazette Republika Ng Philipines. (2020). President Proclamation No. 314, s 1993. https://www.officialgazette.gov.ph/downloads/1993/12dec/19931223PROC-0314-FVR.pdf

Otsuka, K., \& Kalirajan, K. (2010). Community, Market and State in Development: An Introduction. London: Palgrave Macmillan.

Philippine Statistics Authority. (2018). Guimaras Mango Production Slightly Increases : Eat All You Can Consumption Escalates by $74 \%$. http://rsso06.psa.gov.ph/site/default/files/PR020-2018\%20Guimaras\%20mangoes.pdf

Phillips, R., \& Pittman, R. (2014). An Introduction to Community Development. New York: Routledge.

Plunkett, D., Phillips, R., \& Ucar Kocaoglu, B. (2018). Place Attachment and Community Development. Journal of Community Practice, 26(4), 471-482.

128 | Journal of Local Government Issues (Logos), 3 (2), September 2020, pp. 111-129 ISSN : 2620-8091 print | 2620-3812 online 
https://doi.org/10.1080/10705422.2018.1521352

Putnam, R. D. (2007). E Pluribus Unum: Diversity and Community in the Twenty-First Century the 2006 Johan Skytte Prize Lecture. Scandinavian Political Studies, 30(2), 137-174. https://doi.org/10.1111/j.1467-9477.2007.00176.x

Rahman, M. H., \& Yamao, M. (2007). Community Based Organic Farming and Social Capital In Different Network Structures: Studies in Two farming communities in Bangladesh. American Journal of Agricultural and Biological Science, 2(2), 62-68. https://doi.org/10.3844/ajabssp.2007.62.68

Robinson Jr, J. W., \& Green, G. P. (2011). Introduction to Community Development: Theory, Practice, and Service-Learning. London: SAGE Publications.

Sea Knowledge Bank. (2020). Map of the Province of Guimaras in the Philippines. http://seaknowledgebank.net/state-of-the-coasts-reporting-system/guimarasprovince

Sutherland, L., \& Burton, R. (2011). Good farmers, good neighbours. The role of cultural, 3 (1), 238-255. https://doi.org/10.1111/j.1467-9523.2011.00536.x

Tigges, L. M., Browne, I., \& Green, G. P. (1998). Social Isolation of the Urban Poor: Race, Class, and Neighborhood Effects on Social Resources. Sociological Quarterly, 39(1), 53-77. https://doi.org/10.1111/j.1533-8525.1998.tb02349.x

Webb, M. F., Chary, A. N., De Vries, T. T., Davis, S., Dykstra, M., Flood, D., Rohloff, P. (2016). Exploring Mechanisms of Food Insecurity in Indigenous Agricultural Communities in Guatemala: A Mixed Methods Study. BMC Nutrition, 2(1), 1-11. https://doi.org/10.1186/s40795-016-0091-5

Wichtner-Zoia, Y. (2013). What are Community Capitals?, https://www.canr.msu.edu/news/what_are_community_capital 